\title{
Effect of Influent pH and Hydraulic Retention Time on Bioelectricity Generation in an Integrated Acidogenic Reactor and Microbial Fuel Cell Treating Rice Mill Wastewater
}

\author{
Aryama Raychaudhuri \\ Indian Institute of Technology Bhubaneswar \\ Manaswini Behera ( $\sim$ manaswini@iitbbs.ac.in ) \\ Indian Institute of Technology Bhubaneswar https://orcid.org/0000-0003-3829-4916
}

\section{Research Article}

Keywords: Rice mill wastewater treatment, electricity production, acidogenic reactor, volatile fatty acid, microbial fuel cell

Posted Date: August 17th, 2021

DOl: https://doi.org/10.21203/rs.3.rs-776224/v1

License: (c) (1) This work is licensed under a Creative Commons Attribution 4.0 International License. Read Full License 


\section{Abstract}

An innovative design approach was employed in the present study to enhance the electricity generation and wastewater treatment in a microbial fuel cell (MFC). A dual-chambered MFC with a ceramic separator was coupled with an acidogenic chamber. Acidogenic bioconversion of rice mill wastewater into volatile fatty acid (VFA) represents an interesting approach for wastewater valorization. The VFA containing effluent could be used as an effective substrate for bioelectricity generation in MFCs. A short hydraulic retention time (HRT) can be used for the two-stage anaerobic process (acidogenesis and electrogenesis), thus preventing the proliferation of methanogens. The effect of $\mathrm{pH}(5.5-7.5)$ and HRT $(0.5 \mathrm{~d}-0.75 \mathrm{~d})$ were investigated to understand the influence of operational parameters on the performance of the integrated system. The maximum VFA concentration of $1065.15 \pm 5.08 \mathrm{mg} \mathrm{COD} / \mathrm{L}$ was achieved at $\mathrm{pH}$ 7.5 and HRT $0.5 \mathrm{~d}$. Under these operating conditions, the general activity of acid-forming microorganisms and exoelectrogens improved remarkably, and the power density obtained from the system was $4.72 \pm$ $0.10 \mathrm{~W} / \mathrm{m}^{3}$. The current research indicates excellent potential for simultaneous treatment and electricity production from rice mill wastewater. The use of low-cost, locally manufactured, and customized membranes and the two-stage treatment can pave the way for the practical application of this technology.

\section{Introduction}

Rice is crucial for food security, as it is consumed by over half of the world's population. The increasing demand is due to the rising population and burgeoning economies (Doliente and Samsatli 2021). A substantial amount of water is used during the rice parboiling process, generating an effluent $(1-1.2 \mathrm{~L}$ wastewater per kg of paddy) rich in chemical oxygen demand (COD) components (Raychaudhuri et al. 2021). Rice mills are classified as the orange category industry because they generate highly polluting effluent. Despite being less harmful than many other industrial effluents, rice mill wastewater (RMW) requires treatment before disposal (Jayakrishnan et al. 2019). RMW has previously been treated using a variety of technologies, including the upflow anaerobic sludge blanket (UASB) system (Rajesh et al. 1999), electrocoagulation (Karichappan et al. 2013; Choudhary et al. 2015), microalgae uptake (Mukherjee et al. 2016), and adsorption (Thirugnanasambandham et al. 2013; Kumar et al. 2016). However, the above methods suffer from several drawbacks: extended retention periods, sludge disposal issues, high cost of materials, and inadequate COD removal.

Microbial fuel cell (MFC) technology has received considerable attention due to its ability to treat wastewater while also generating energy, resolving two of the most crucial environmental issues: water shortage and depletion of natural resources. MFCs have the potential to transform traditional wastewater treatment plants into resource retrieval facilities by direct power generation from the organic component of wastewater. RMW can be treated in MFC owing to its readily biodegradable organic content (Behera et al. 2010). Valorization of effluent may increase the revenue of small-scale industries by lowering waste treatment costs. Acidification of RMW to increase the volatile fatty acid (VFA) concentration prior to its application in MFC will enhance the electricity generation as exoelectrogens preferentially utilize simple 
dissolved organic acids (mainly acetic acid) (Chen et al. 2013). Relevant literature on the acidogenic potential of RMW is scarce. Hence, further investigation towards the acidification of RMW for improving the VFA generation and subsequent use in MFC is imperative to fill the research gap.

Operating parameters such as substrate type, temperature, $\mathrm{pH}$, hydraulic retention time (HRT), COD loading rate have been identified as important factors in improving VFA production during acidogenesis (Hong and Haiyun 2010; Khan et al. 2016). The pH of the electrolyte is a crucial factor influencing the power output of the MFC. The anodic $\mathrm{pH}$ is the most critical factor that can affect the bacterial metabolic activity and, as a result, the electron and proton production mechanisms. In general, bacteria regulate their activity in response to internal and external $\mathrm{pH}$ variations through various activities, including proton translocation, protein breakdown, and adjustment to acidic or basic environments (Raghavulu et al. 2009). It is well established that low methanogenic activity is required for high acidogenesis efficiency. Thus, short HRT is commonly employed (2-10 h) to facilitate the suppression of methanogenic bacteria (Ponsá et al. 2008; Venkata Mohan et al. 2019). Accordingly, a short HRT can be employed during the operation of a two-stage anaerobic process (acidogenesis and electrogenesis), preventing the proliferation of methanogens (Raychaudhuri and Behera 2021). So, in the present study, an attempt has been made to examine the effect of acidification of RMW and thereafter utilizing it as a substrate in MFC. An acidification chamber was coupled with a dual-chambered MFC, and acidification of real RMW was performed in the chamber before it was introduced into the dual-chambered MFC. The system was operated at feed pH of 5.5 and7.5 and HRT $0.5 \mathrm{~d}$ and $0.75 \mathrm{~d}$. The performance of the coupled acidogenic reactor and MFC system in terms of VFA production from the acidogenic chamber, power production from MFC, and organic matter removal was investigated. To the best knowledge of the authors, no previous research has considered such RMW pretreatment and examined its impact on the MFC performance in terms of organics removal and power generation.

\section{Materials And Methods}

\section{Collection of rice mill wastewater and anaerobic inoculum}

The RMW was obtained from the rice parboiling unit of a local rice mill near Khurda Industrial Estate, Odisha, India. Table 1 summarizes the characteristics of rice parboiling effluent. The RMW was diluted (COD $=1996 \pm 11.5 \mathrm{mg} / \mathrm{L})$ before adding to the reactors. After collecting anaerobic inoculum from the bottom of a pond, it was sieved using a screen $(1.18 \mathrm{~mm})$. The inoculum was incubated for 2 days at 35 ${ }^{\circ} \mathrm{C}$ under anaerobic conditions, and the $\mathrm{pH}$ of the sludge was adjusted to 5.5. To suppress methanogens and select spore-forming acetogens, the sludge was kept at $100{ }^{\circ} \mathrm{C}$ for $15 \mathrm{~min}$ and then cooled down to room temperature prior to inoculation (Perimenis et al. 2018).

Table 1 The characteristics of rice mill wastewater from the parboiling unit. 


\begin{tabular}{|lll|}
\hline Parameter & Unit & Value \\
\hline $\mathrm{pH}$ & - & $5.1 \pm 0.6$ \\
\hline Color & Co-Pt & $1649.2 \pm 2.7$ \\
\hline Soluble BOD 5 & $\mathrm{mg} / \mathrm{L}$ & $1348 \pm 7.1$ \\
\hline Soluble COD & $\mathrm{mg} / \mathrm{L}$ & $3045 \pm 17.6$ \\
\hline Soluble TOC & $\mathrm{mg} / \mathrm{L}$ & $1387.5 \pm 11.6$ \\
\hline Turbidity & $\mathrm{NTU}$ & $172 \pm 5$ \\
\hline Conductivity & $\mathrm{mS} / \mathrm{cm}$ & $4.8 \pm 0.07$ \\
\hline Lignin & $\mathrm{mg} / \mathrm{L}$ & $465.5 \pm 0.8$ \\
\hline Phenol & $\mathrm{mg} / \mathrm{L}$ & $4.84 \pm 0.12$ \\
\hline
\end{tabular}

\section{Reactor fabrication, inoculation, and operation}

The acidogenic reactor-MFC coupled system was fabricated using an acrylic sheet (thickness: $6 \mathrm{~mm}$ ) having two rectangular chambers with net liquid volumes of $1 \mathrm{~L}$ and $2.3 \mathrm{~L}$. The chamber with a volume of $1 \mathrm{~L}$ was considered the acidogenic chamber, and the second compartment was regarded as the cathode chamber of the MFC (Fig. 1). A cuboid-shaped anode chamber, having $5 \mathrm{~mm}$ thick ceramic separators (Raychaudhuri and Behera 2020) on the four walls, was positioned inside the cathode chamber. RMW was supplied to the acidogenic reactor using a peristaltic pump through an inlet at the lower end of the chamber to promote upward flow. By means of a pipe, the effluent from the acidogenic chamber was collected from its top and channeled to the bottom of the anode chamber.

A stainless-steel mesh with a surface area of $185 \mathrm{~cm}^{2}$ and four graphite plates with a surface area of 116 $\mathrm{cm}^{2}$ were used as anode and cathode electrodes. The electrodes were connected to a $100 \Omega$ external resistor using enameled copper wires. Both the acidogenic chamber and the anode chamber were provided with an opening at the top to facilitate sample collection and monitoring. The openings were firmly closed during operation to prevent oxygen diffusion. As a catholyte, tap water was used, and an air pump was employed to keep it continuously aerated. The reactors were operated in continuous mode while maintaining the desired HRT $(0.5 \mathrm{~d}$ and $0.75 \mathrm{~d})$ for 30 days until the steady-state was reached. The influent $\mathrm{pH}$ (5.5 and 7.5) was maintained accordingly. Before being inoculated into the MFC, the sieved sludge was heated for $15 \mathrm{~min}$ at $105^{\circ} \mathrm{C}$ to eliminate methanogenic bacteria.

\section{Electrochemical measurements and analysis}

The open-circuit voltage (OCV) and the operating voltage (OV) were evaluated using a digital multimeter with a data acquisition unit (Keysight 34972A). The power density (normalized to net liquid volume of anode) was measured according to $P\left(W / m^{3}\right)=V^{2} / R \cdot V_{a}$, where $V$ is the operating voltage in Volts, $R$ is the 
external resistance $(100 \Omega)$, and $\mathrm{V}_{\mathrm{a}}$ is the net liquid volume in the anode chamber $(480 \mathrm{~mL})$. The maximum power densities (normalizing power to anode surface area) were measured in the polarization analysis (after attaining steady-state) by varying the external resistance from $10,000 \Omega$ to $10 \Omega$, beginning with the open circuit condition (Metravi resistance box). A potentiostat (Ivium technologies) and software (Ivium) were used to conduct linear sweep voltammetry (LSV) and cyclic voltammetry (CV) experiments. LSV and CV were conducted using a three-electrode arrangement with the anode as the working electrode, the cathode as the counter electrode, and the $\mathrm{Ag} / \mathrm{AgCl}$ electrode as the reference electrode (placed in the anode chamber). For both LSV and CV, a scan rate of $10 \mathrm{mV} / \mathrm{s}$ was used, and the current response was recorded accordingly (Wei et al. 2013). The electrochemical impedance spectroscopy (EIS) analysis was carried out to understand different impedance components. The whole-cell arrangement was employed with anode as a working electrode and cathode as counter and reference electrode. A frequency range of $100 \mathrm{kHz}$ to $1 \mathrm{mHz}$ was employed using an AC signal. To simulate EIS data, Nyquist impedance spectra were analyzed, and the data were fitted using Randles equivalent circuit. The real part of impedance was depicted on the $x$-axis in the Nyquist plot, while the imaginary part was presented on the $y$-axis, with each point in the Nyquist plot corresponding to the impedance at a particular frequency (Ramaraja $\mathrm{P}$ Ramasamy 2013).

\section{Chemical analytical measurements and calculations}

The closed reflux colorimetric method was used to determine the COD of the effluents from the acidogenic reactor and MFC. Total organic carbon (TOC) was assessed using a TOC analyzer. Lignin was analyzed according to standard methods. High-performance liquid chromatography (HPLC) (Ultimate 3000 , DIONEX, USA) with a quaternary pump and autosampler calibrated to $20 \mu \mathrm{L}$ injection volume, and a C-18 column (HYPERSIL GOLD 5UM, Thermo scientific, $250 \mathrm{~mm} \times 4.6 \mathrm{~mm}$ ) was used to test four VFAs: acetic acid, propionic acid, butyric acid, and valeric acid. A combination of potassium dihydrogen phosphate and methanol was utilized as mobile phase. (Zotou et al. 2004; De Sena Aquino et al. 2015). The mobile phases were eluted at a flow rate of $0.6 \mathrm{~mL} / \mathrm{min}$ using an isocratic elution technique. The data was obtained using Chromeleon 7 software, and the retention periods were analyzed using UVvisible spectra to identify the peaks (at a wavelength of $220 \mathrm{~nm}$ ). Prior to HPLC analysis, the samples were filtered through a $0.22 \mu \mathrm{m}$ filter (Raychaudhuri and Behera 2021).

VFA concentration was measured as the COD equivalent based on the complete oxidation of the specific substance to carbon dioxide and water. The conversion factors for COD to different VFA were 1.07 for acetic acid, 1.51 for propionic acid, 1.82 for butyric acid, and 2.04 for valeric acid (Wang et al. 2014; Yin et al. 2016). The acidification yield $\left(\eta_{a}\right)$ was estimated using Eq. (1)

$$
\eta_{a}=\frac{V F A_{\text {out }}}{C O D_{\text {out }}} \times 100 \%
$$

Where, $\mathrm{COD}_{\text {out }}$ is the concentration of the soluble $\mathrm{COD}(\mathrm{mg} / \mathrm{L})$, and VFA $\mathrm{out}_{\text {is }}$ is the concentration of total VFA (mg COD/L) in the effluent of the acidogenic reactor (Jankowska et al. 2018). 


\section{Results And Discussion}

\section{Effect of operating $\mathrm{pH}$ and HRT on VFA generation and power production}

Influent $\mathrm{pH}$ and HRT are important process control parameters that can be manipulated to achieve desired acidification products. In extreme acidic $(\mathrm{pH} 3)$ or alkaline $(\mathrm{pH} 12)$ conditions, acidogens involved in the production of VFA cannot survive, and appropriate influent $\mathrm{pH}$ is necessary to optimize VFA production. It is known that optimum pH for VFA production is highly dependent on the nature of the substrate used (Kuruti et al. 2017). In this study, pH value of 5.5 and 7.5 was selected. The HRT of the system was maintained at $0.5 \mathrm{~d}$ and $0.75 \mathrm{~d}$ corresponding to an HRT in the acidogenic reactor in the range of $8 \mathrm{~h}$ and $12 \mathrm{~h}$. Table 2 summarizes the total concentration and distribution of different VFAs and the degree of acidification. The VFA concentration in the acidogenic reactor varied between $728.76 \mathrm{mg}$ $\mathrm{COD} / \mathrm{L}$ and $663.65 \mathrm{mg} \mathrm{COD} / \mathrm{L}$ at influent $\mathrm{pH}$ of 5.5 , and $1065.15 \mathrm{mg} \mathrm{COD} / \mathrm{L}$ and $813.25 \mathrm{mg} \mathrm{COD} / \mathrm{L}$ at influent pH of 7.5 when the HRT range was $0.5 \mathrm{~d}$ to $0.75 \mathrm{~d}$. The inhibition effects induced by the permeability of undissociated acids through the cellular membrane influence the rate of acidification. Transport of the undissociated acid requires high energy at lower $\mathrm{pH}$ levels, while transportation of the free state of the acid consumes less energy at higher pH levels (Rodríguez et al. 2006). On the other hand, hydrolysis of complex carbohydrates present in rice mill wastewater (cellulose and lignin) occurs in alkaline $\mathrm{pH}$, enhancing the acidification efficiency (Ramos-Suarez et al., 2021). It was reported that a pH of 7.0 was optimal for hydrolysis and acidogenesis of kitchen waste because it resulted in the maximum VFAconcentration compared to other pH values (Zhang et al. 2005). Similar results were reported for food wastes and dewatered excess sludge (Hong and Haiyun 2010), for which pH 7 favored VFA production compared with other alkaline and acidic pHs. The decrease of VFA concentration with increasing HRT might be explained by the growth of VFA scavengers such as methanogens. At low pH values (pH 5.5), the dominant VFA was propionic acid and acetic acid, whereas the production of VFA shifted towards butyric acid and acetic acid ( $\mathrm{pH} 7.5)$ with the increase in $\mathrm{pH}$. Similar results were reported by GarciaAguirre et al. (2017) during anaerobic fermentation of different organic waste streams, in which propionic acid was produced in the acidic range, while acetic acid production increased when the $\mathrm{pH}$ was shifted to alkaline range.

Table 2 Total VFA concentration and distribution of different VFAs. 


\begin{tabular}{|c|c|c|c|c|c|c|}
\hline \multirow{2}{*}{$\begin{array}{l}\text { Operational } \\
\text { condition }\end{array}$} & \multirow{2}{*}{$\begin{array}{l}\text { Total } \\
\text { VFA } \\
\text { (mg } \\
\text { COD/L) }\end{array}$} & \multirow{2}{*}{$\begin{array}{l}\text { Degree of } \\
\text { acidification (\%) }\end{array}$} & \multicolumn{4}{|c|}{ VFA composition (mg COD/L) } \\
\hline & & & $\begin{array}{l}\text { Acetic } \\
\text { acid }\end{array}$ & $\begin{array}{l}\text { Propionic } \\
\text { acid }\end{array}$ & $\begin{array}{l}\text { Butyric } \\
\text { acid }\end{array}$ & $\begin{array}{l}\text { Valeric } \\
\text { acid }\end{array}$ \\
\hline $\mathrm{pH} 7.5$ & 1065.15 & 81.15 & 592.12 & 104.69 & 282.84 & 85.50 \\
\hline \multicolumn{7}{|l|}{ HRT $0.5 d$} \\
\hline $\mathrm{pH} 7.5$ & 813.25 & 74.65 & 308.36 & 131.97 & 245.45 & 127.46 \\
\hline \multicolumn{7}{|l|}{ HRT $0.75 d$} \\
\hline pH 5.5 & 728.76 & 67.87 & 295.55 & 267.879 & 122.20 & 43.12 \\
\hline \multicolumn{7}{|l|}{ HRT $0.5 \mathrm{~d}$} \\
\hline pH 5.5 & 663.65 & 60.87 & 162.86 & 285.638 & 113.10 & 102.05 \\
\hline HRT $0.75 d$ & & & & & & \\
\hline
\end{tabular}

\section{Voltage output and polarization behavior}

At steady-state condition, the OCV, OV, and power density (normalized to net liquid volume in anode) achieved in the acidogenic reactor-MFC system at pH 7.5 were $858 \pm 5.7 \mathrm{mV}, 476 \pm 5.2 \mathrm{mV}$, and $4.72 \pm 0.10$ $\mathrm{W} / \mathrm{m}^{3}$, respectively for HRT $0.5 \mathrm{~d}, 812.2 \pm 4.2 \mathrm{mV}, 401.1 \pm 3.7 \mathrm{mV}, 3.35 \pm 0.06 \mathrm{~W} / \mathrm{m}^{3}$, respectively for HRT $0.75 \mathrm{~d}$, and at pH 5.5 were $784.3 \pm 5.6 \mathrm{mV}, 387.4 \pm 4.9 \mathrm{mV}, 3.12 \pm 0.08 \mathrm{~W} / \mathrm{m}^{3}$, respectively for HRT $0.5 \mathrm{~d}$, $755.2 \pm 3.8 \mathrm{mV}, 346.3 \pm 4.8 \mathrm{mV}, 2.49 \pm 0.07 \mathrm{~W} / \mathrm{m}^{3}$, respectively for HRT $0.75 \mathrm{~d}$. The findings of the present work suggested that at a lower HRT and higher $\mathrm{pH}$, the methanogens were suppressed; thus more VFAs were available for the electrogens; hence system performance improved drastically.

In polarization study, the maximum power density (obtained by normalizing power to anode surface area) obtained at $\mathrm{pH} 7.5$ were $131.78 \mathrm{~mW} / \mathrm{m}^{2}$ (at HRT $0.5 \mathrm{~d}$ ) and $89.50 \mathrm{~mW} / \mathrm{m}^{2}$ (at HRT $0.75 \mathrm{~d}$ ) and at $\mathrm{pH} 5.5$ were $78.69 \mathrm{~mW} / \mathrm{m}^{2}$ (at HRT $0.5 \mathrm{~d}$ ) 67.76 and $\mathrm{mW} / \mathrm{m}^{2}$ (at HRT $0.75 \mathrm{~d}$ ). The results obtained were illustrated in Fig. 2. There are three main sections to the polarization curve. The charge transfer overpotential causes the first component to occur in the low current density area. The second area is characterized by slow ohmic voltage losses that are linear in most circumstances. The mass transfer overpotential and concentration polarization are described in the third section of the polarization curve. The VFAs produced in the acidogenic reactor enhanced the conductivity of the anodic electrolyte, lowering resistance to ion transport through the membrane. The reduction of bacterial metabolic losses was attributable to the enrichment of exoelectrogens in the anode of MFC.

\section{Electrochemical assessments}

Voltammetry investigations were conducted to examine the biocatalytic performances of the anodic biofilm. The LSV is performed to examine the potential of exoelectrogens to produce current in response to an applied voltage. The anode of the MFC system operated under pH 7.5 and HRT 0.5 d exhibited an 
almost three times higher current response than the anode of the MFC system operated under $\mathrm{pH} 5.5$ and HRT $0.75 \mathrm{~d}$ (Fig. 3a). CV is an electroanalytical technique that offers insights into an electrochemical system and assists in understanding electrochemical reactions at the electrodes (Khajeh et al. 2020). An oxidation peak and a reduction peak were observed at $0.51 \mathrm{~V}$ and $-0.2 \mathrm{~V}$ for the MFC system operated under $\mathrm{pH} 7.5$ and HRT $0.5 \mathrm{~d}$ (Fig. 3b). The enrichment of exoelectrogenic bacteria induces the production of redox mediators and membrane-bound proteins, which in turn improves the electrocatalytic activity of the biofilm. The enhanced current response in the MFC system operated under $\mathrm{pH} 7.5$ and HRT $0.5 \mathrm{~d}$ reveals that electrogenic bacteria utilize the substrate effectively, implying that the VFA rich anolyte enriches the electroactive bacteria population.

EIS is an electrochemical tool that contributes to a better understanding of individual impedance components. Three key resistance components can characterize total impedance. In the Nyquist plot, charge transfer resistance $\left(R_{C T}\right)$ is indicated by the semicircle diameter, and the ohmic resistance $\left(R_{\Omega}\right)$ was represented by the distance between the origin and the beginning of the semicircle (Fig. 4).

$R_{\Omega}$ of the MFCs is affected by the distance between electrodes, the contact between electrode and wire, conductivity of the membrane, and electrolyte solution. The $\mathrm{R}_{\mathrm{CT}}$ depends on the rate at which an electron is transferred from ionic species in the solution to a solid electrode during the electron transfer process. Double-layer capacitance $\left(\mathrm{C}_{\mathrm{dl}}\right)$ is equivalent to a capacitor in an electrical circuit that corresponds to the charge separation or electrical double layer, present at the interphase between the electrode and electrolyte, cation exchange membrane, etc. (Tamilarasan et al. 2017; Raychaudhuri and Behera 2020). In the current investigation, the difference in the $\mathrm{R}_{\Omega}$ is primarily dependent on variations in solution resistance. A higher concentration of VFA in the acidified effluent of the system operated under $\mathrm{pH} 7.5$, and HRT $0.5 \mathrm{~d}$, decreased electrolyte resistance in the anode (Table 3). A considerable decrease of $R_{C T}$ can be achieved with a significant increase in redox-active mediators in the anolyte. The prevalence of exoelectrogens in the anode surface regulates the release of such mediators. A lower $\mathrm{R}_{\mathrm{CT}}$ value may be related to the enrichment of electroactive biofilm on the anode surface. The impedance of a capacitor is inversely proportional to its capacitance. The higher $C_{d l}$ value indicates that the capacitor primarily charges or discharges and will thus pass more current.

Table 3 Impedance components derived from Nyquist plot and Randles equivalent circuit.

\begin{tabular}{|llll|}
\hline Operational condition & $\mathbf{R}_{\mathbf{Q}}(\Omega)$ & $\mathbf{R}_{\mathrm{CT}}(\Omega)$ & $\mathbf{C}_{\mathrm{dl}}(\boldsymbol{\mu} \mathrm{F})$ \\
\hline pH 7.5, HRT 0.5 d & 27.9 & 21.7 & 250 \\
\hline pH 7.5, HRT 0.75 d & 54.4 & 24.7 & 103 \\
\hline pH 5.5, HRT 0.5 d & 68.8 & 40.3 & 2.16 \\
\hline pH 5.5, HRT 0.75 d & 97.7 & 44.8 & 2.29 \\
\hline
\end{tabular}


Under the steady-state condition, the COD, TOC, and lignin removal efficiencies of the acidogenic reactorMFC systems were illustrated in Fig. 5. The higher VFA concentration in the anolyte of the MFC system operated under $\mathrm{pH} 7.5$ and HRT $0.5 \mathrm{~d}$, attributed to the higher pollutant removal as exoelectrogens readily oxidized simpler organics. A higher HRT exhibited a higher COD removal might be due to the growth of methanogens, subsequently reducing the electron yield. Previous research has demonstrated $78 \%$ COD removal in $0.17 \mathrm{~d}$ in a two-chamber up-flow MFC producing electricity from xylose (Haavisto et al. 2017). A COD removal efficiency of $92 \%$ was reported in $0.69 \mathrm{~d}$ in a dual-chambered MFC (Ye et al. 2020). The lignin removal efficiencies were found in the range of $49-68 \%$. Due to the enriched electroactive biofilm in the anode of MFC, complex organics like lignin were degraded efficiently. Fig. 6 demonstrates a comparative performance assessment acidogenic reactor-MFC systems (operated under four operating conditions) regarding the OCV, OV, power normalized to the net liquid volume of anode chamber, COD removal efficiency, ohmic resistance, and VFA concentration.

\section{Conclusions}

The present study investigated the effect of $\mathrm{pH}$ and HRT on the acidification efficiency and power output in an integrated acidogenic reactor and MFC during the treatment of RMW. It was observed that at $\mathrm{pH} 7.5$ and HRT $0.5 \mathrm{~d}$, the VFA concentration in the acidified effluent was maximum. VFA concentration achieved was $1065.15 \pm 5.08 \mathrm{mg} \mathrm{COD} / \mathrm{L}$, which comprised $55.6 \%$ acetic acid, $26.5 \%$ butyric acid, $9.9 \%$ propionic acid, and $8 \%$ valeric acid. Under the operating condition, a power density of $4.72 \pm 0.10 \mathrm{~W} / \mathrm{m}^{3}$ was achieved, which is 1.9 times higher than the power density obtained under pH 5.5 and HRT $0.75 \mathrm{~d}$. The findings of the present work suggested that at a lower HRT and higher $\mathrm{pH}$, the methanogens were suppressed; thus, more VFAs were available for the exoelectrogens; hence system performance improved drastically.

\section{Declarations}

\section{Acknowledgments}

The authors would like to acknowledge the financial support by the Department of Science and Technology, New Delhi, Government of India, under grant no. EEQ/2016/00097. The fellowship of the first author received from the Ministry of Human Resources Development (MHRD), Government of India, is also acknowledged.

Funding Department of Science and Technology, New Delhi, Government of India, under grant no. EEQ/2016/00097.

Data availability All data generated or analyzed during this study are included in this published article

Ethics approval and consent to participate Not applicable

Consent for publication Not applicable 
Competing interests The authors declare no competing interests

Authors' contributions Aryama Raychaudhuri: Conceptualization, Investigation, Data Collection, Analysis, Writing - Original Draft.

Manaswini Behera: Supervision, Conceptualization, Writing - review \& editing, Funding acquisition.

\section{References}

Behera M, Jana PS, More TT, Ghangrekar MM (2010) Rice mill wastewater treatment in microbial fuel cells fabricated using proton exchange membrane and earthen pot at different $\mathrm{pH}$. Bioelectrochemistry 79:228-233. https://doi.org/10.1016/j.bioelechem.2010.06.002

Chen Y, Luo J, Yan Y, Feng L (2013) Enhanced production of short-chain fatty acid by co-fermentation of waste activated sludge and kitchen waste under alkaline conditions and its application to microbial fuel cells. Appl Energy 102:1197-1204. https://doi.org/10.1016/j.apenergy.2012.06.056

Choudhary M, Majumder S, Neogi S (2015) Studies on the Treatment of Rice Mill Effluent by Electrocoagulation. Sep Sci Technol 50:505-511. https://doi.org/10.1080/01496395.2014.956225

De Sena Aquino ACM, Azevedo MS, Ribeiro DHB, et al (2015) Validation of HPLC and CE methods for determination of organic acids in sour cassava starch wastewater. Food Chem. https://doi.org/10.1016/j.foodchem.2014.09.142

Doliente SS, Samsatli S (2021) Integrated production of food, energy, fuels and chemicals from rice crops: Multi-objective optimisation for efficient and sustainable value chains. J Clean Prod 285:124900. https://doi.org/10.1016/j.jclepro.2020.124900

Garcia-Aguirre J, Aymerich E, González-Mtnez. de Goñi J, Esteban-Gutiérrez M (2017) Selective VFA production potential from organic waste streams: Assessing temperature and $\mathrm{pH}$ influence. Bioresour Technol 244:1081-1088. https://doi.org/10.1016/j.biortech.2017.07.187

Haavisto JM, Kokko ME, Lay C-H, Puhakka JA (2017) Effect of hydraulic retention time on continuous electricity production from xylose in up-flow microbial fuel cell. Int J Hydrogen Energy 42:27494-27501. https://doi.org/10.1016/j.jjhydene.2017.05.068

Hong C, Haiyun W (2010) Optimization of volatile fatty acid production with co-substrate of food wastes and dewatered excess sludge using response surface methodology. Bioresour Technol 101:5487-5493. https://doi.org/10.1016/j.biortech.2010.02.013

Jankowska E, Duber A, Chwialkowska J, et al (2018) Conversion of organic waste into volatile fatty acids - The influence of process operating parameters. Chem Eng J. https://doi.org/10.1016/j.cej.2018.03.180 
Jayakrishnan U, Deka D, Das G (2019) Enhancing the volatile fatty acid production from agro-industrial waste streams through sludge pretreatment. Environ Sci Water Res Technol 5:334-345. https://doi.org/10.1039/c8ew00715b

Karichappan T, Venkatachalam S, Jeganathan PM, Sengodan K (2013) Treatment of rice mill wastewater using continuous electrocoagulation technique: Optimization and modelling. J Korean Chem Soc 57:761-768. https://doi.org/10.5012/jkcs.2013.57.6.761

Khajeh RT, Aber S, Nofouzi K, Ebrahimi S (2020) Treatment of mixed dairy and dye wastewater in anode of microbial fuel cell with simultaneous electricity generation. Environ Sci Pollut Res 27:43711-43723. https://doi.org/10.1007/s11356-020-10232-1/Published

Khan MA, Ngo HH, Guo WS, et al (2016) Optimization of process parameters for production of volatile fatty acid, biohydrogen and methane from anaerobic digestion. Bioresour Technol 219:738-748. https://doi.org/10.1016/j.biortech.2016.08.073

Kumar A, Priyadarshinee R, Singha S, et al (2016) Rice husk ash-based silica-supported iron catalyst coupled with Fenton-like process for the abatement of rice mill wastewater. Clean Technol Environ Policy 18:2565-2577. https://doi.org/10.1007/s10098-016-1165-4

Kuruti K, Nakkasunchi S, Begum S, et al (2017) Rapid generation of volatile fatty acids (VFA) through anaerobic acidification of livestock organic waste at low hydraulic residence time (HRT). Bioresour Technol 238:188-193. https://doi.org/10.1016/j.biortech.2017.04.005

Mukherjee C, Chowdhury R, Sutradhar T, et al (2016) Parboiled rice effluent: A wastewater niche for microalgae and cyanobacteria with growth coupled to comprehensive remediation and phosphorus biofertilization. Algal Res 19:225-236. https://doi.org/10.1016/j.algal.2016.09.009

Perimenis A, Nicolay T, Leclercq M, Gerin PA (2018) Comparison of the acidogenic and methanogenic potential of agroindustrial residues. Waste Manag 72:178-185.

https://doi.org/10.1016/j.wasman.2017.11.033

Ponsá S, Ferrer I, Vázquez F, Font X (2008) Optimization of the hydrolytic-acidogenic anaerobic digestion stage $\left(55^{\circ} \mathrm{C}\right)$ of sewage sludge: Influence of $\mathrm{pH}$ and solid content. Water Res 42:3972-3980. https://doi.org/10.1016/j.watres.2008.07.002

Raghavulu SV, Mohan SV, Goud RK, Sarma PN (2009) Effect of anodic pH microenvironment on microbial fuel cell (MFC) performance in concurrence with aerated and ferricyanide catholytes. Electrochem commun 11:371-375. https://doi.org/10.1016/J.ELECOM.2008.11.038

Rajesh G, Bandyopadhyay M, Das D (1999) Some studies on UASB bioreactors for the stabilization of low strength industrial effluents. Bioprocess Eng 21:113. https://doi.org/10.1007/s004490050649 
Ramaraja P Ramasamy NS (2013) Electrochemical Impedance Spectroscopy for Microbial Fuel Cell Characterization. J Microb Biochem Technol. https://doi.org/10.4172/1948-5948.S6-004

Raychaudhuri A, Behera M (2021) Enhancement of bioelectricity generation by integrating acidogenic compartment into a dual-chambered microbial fuel cell during rice mill wastewater treatment. Process Biochem. https://doi.org/10.1016/j.procbio.2021.03.003

Raychaudhuri A, Behera M (2020) Ceramic membrane modified with rice husk ash for application in microbial fuel cells. Electrochim Acta 363:137261. https://doi.org/10.1016/j.electacta.2020.137261

Raychaudhuri A, Sahoo RN, Behera M (2021) Application of clayware ceramic separator modified with silica in microbial fuel cell for bioelectricity generation during rice mill wastewater treatment. Water Sci Technol 84:66-76. https://doi.org/10.2166/wst.2021.213

Rodríguez J, Kleerebezem R, Lema JM, van Loosdrecht MCM (2006) Modeling product formation in anaerobic mixed culture fermentations. Biotechnol Bioeng 93:592-606.

https://doi.org/10.1002/bit.20765

Tamilarasan K, Banu JR, Jayashree C, et al (2017) Effect of organic loading rate on electricity generating potential of upflow anaerobic microbial fuel cell treating surgical cotton industry wastewater. J Environ Chem Eng 5:1021-1026. https://doi.org/10.1016/j.jece.2017.01.025

Thirugnanasambandham K, Sivakumar V, Prakash Maran J (2013) Application of chitosan as an adsorbent to treat rice mill wastewater-Mechanism, modelling and optimization. Carbohydr Polym 97:451-457. https://doi.org/10.1016/j.carbpol.2013.05.012

Venkata Mohan S, Chiranjeevi P, Chandrasekhar K, et al (2019) Acidogenic Biohydrogen Production From Wastewater. In: Biohydrogen. Elsevier, pp 279-320

Wang K, Yin J, Shen D, Li N (2014) Anaerobic digestion of food waste for volatile fatty acids (VFAs) production with different types of inoculum: Effect of $\mathrm{pH}$. Bioresour Technol. https://doi.org/10.1016/j.biortech.2014.03.088

Wei B, Tokash JC, Zhang F, et al (2013) Electrochemical analysis of separators used in single-chamber, air-cathode microbial fuel cells. Electrochim Acta 89:45-51.

https://doi.org/10.1016/j.electacta.2012.11.004

Ye Y, Ngo HH, Guo W, et al (2020) Impacts of hydraulic retention time on a continuous flow mode dualchamber microbial fuel cell for recovering nutrients from municipal wastewater. Sci Total Environ. https://doi.org/10.1016/j.scitotenv.2020.139220

Yin J, Yu X, Zhang Y, et al (2016) Enhancement of acidogenic fermentation for volatile fatty acid production from food waste: Effect of redox potential and inoculum. Bioresour Technol. https://doi.org/10.1016/j.biortech.2016.06.053

Page 12/18 
Zhang B, Zhang L-L, Zhang S-C, et al (2005) The Influence of pH on Hydrolysis and Acidogenesis of Kitchen Wastes in Two-phase Anaerobic Digestion. Environ Technol 26:329-340.

https://doi.org/10.1080/09593332608618563

Zotou A, Loukou Z, Karava O (2004) Method development for the determination of seven organic acids in wines by reversed-phase high performance liquid chromatography. Chromatographia.

https://doi.org/10.1365/s10337-004-0330-9

\section{Figures}

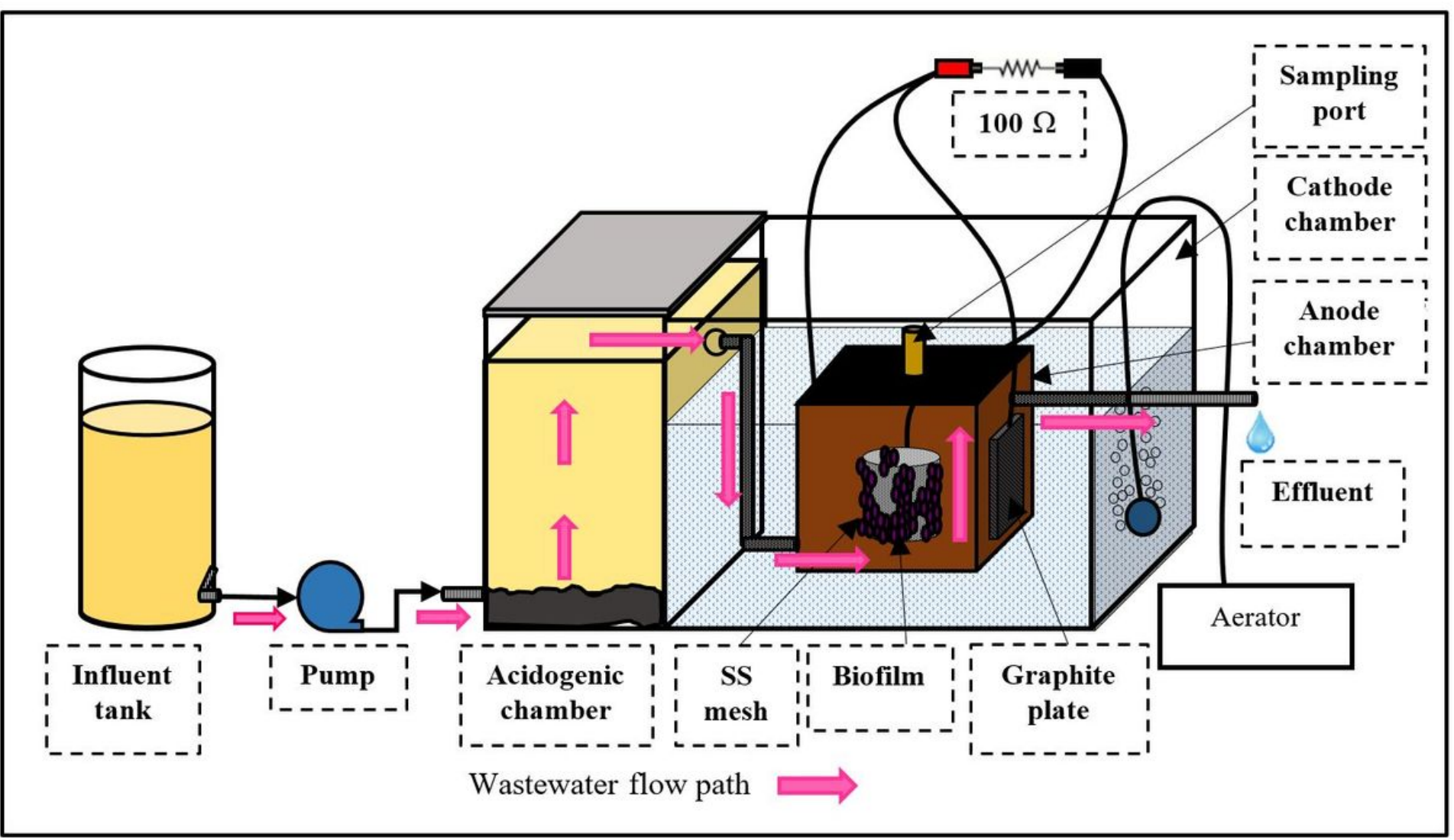

Figure 1

Schematic depiction of the acidogenic chamber-MFC coupled system. 


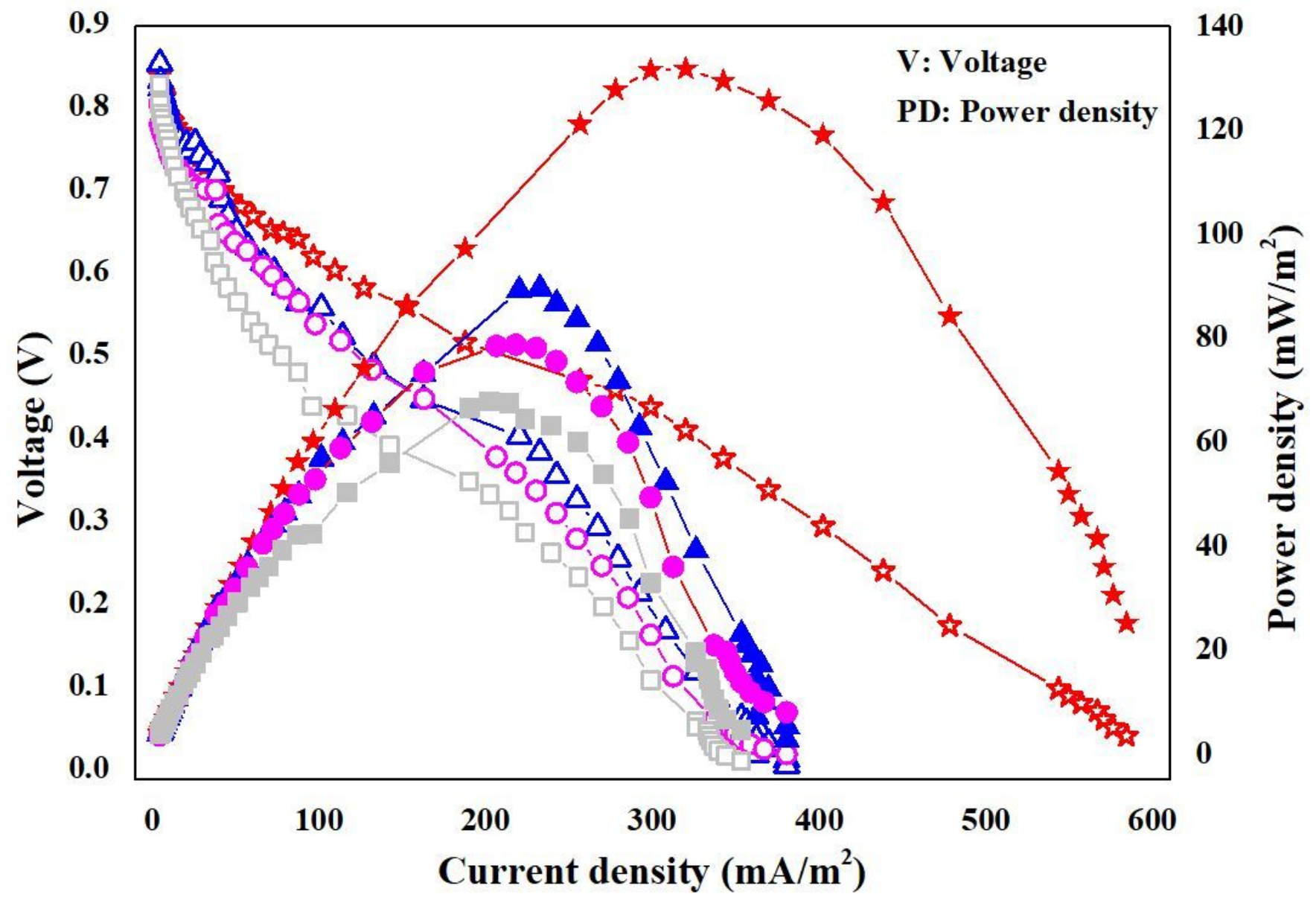

$-\star-\mathrm{pH}_{7.5} \mathrm{HRT}_{0.5 \mathrm{~d}}(\mathrm{~V})-\Delta-\mathrm{pH}_{7.5} \mathrm{HRT}_{0.75 \mathrm{~d}}(\mathrm{~V})-\mathrm{O}-\mathrm{pH}_{5.5} \mathrm{HRT}_{0.5 \mathrm{~d}}(\mathrm{~V})-\square-\mathrm{pH}_{5.5} \mathrm{HRT}_{0.75 \mathrm{~d}}(\mathrm{~V})$
$-\star-\mathrm{pH}_{7.5} \mathrm{HRT}_{0.5 \mathrm{~d}}(\mathrm{PD})-\Delta-\mathrm{pH}_{7.5} \mathrm{HRT}_{0.75 \mathrm{~d}}(\mathrm{PD})---\mathrm{pH}_{5.5} \mathrm{HRT}_{0.5 \mathrm{~d}}(\mathrm{PD})-\square-\mathrm{pH}_{5.5} \mathrm{HRT}_{0.75 \mathrm{~d}}(\mathrm{PD}$

Figure 2

Polarization and power density curves of the integrated acidogenic reactor and MFC system at different operational conditions. 

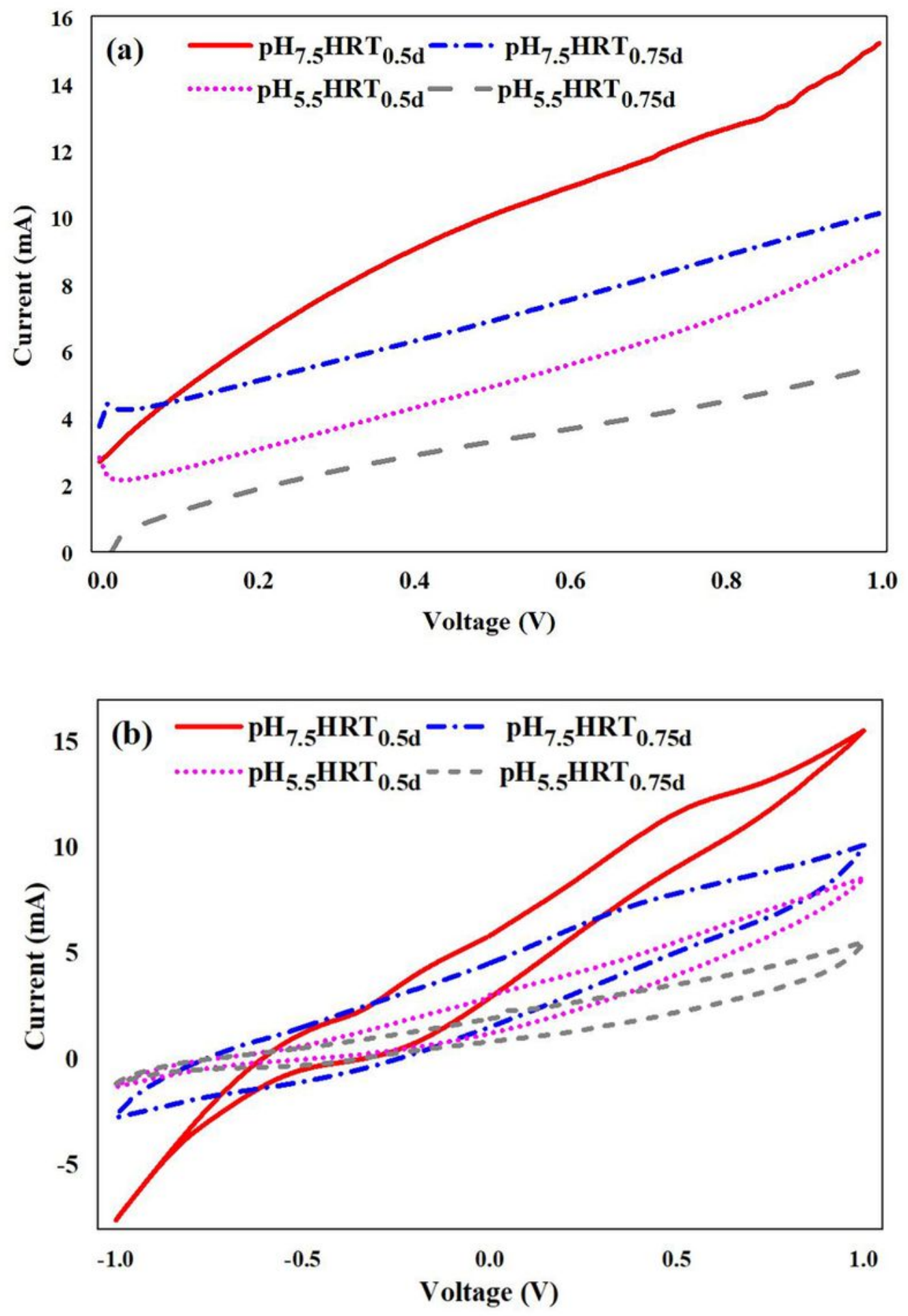

Figure 3

(a) LSV and (b) CV profiles of the coupled system at various operating conditions. 


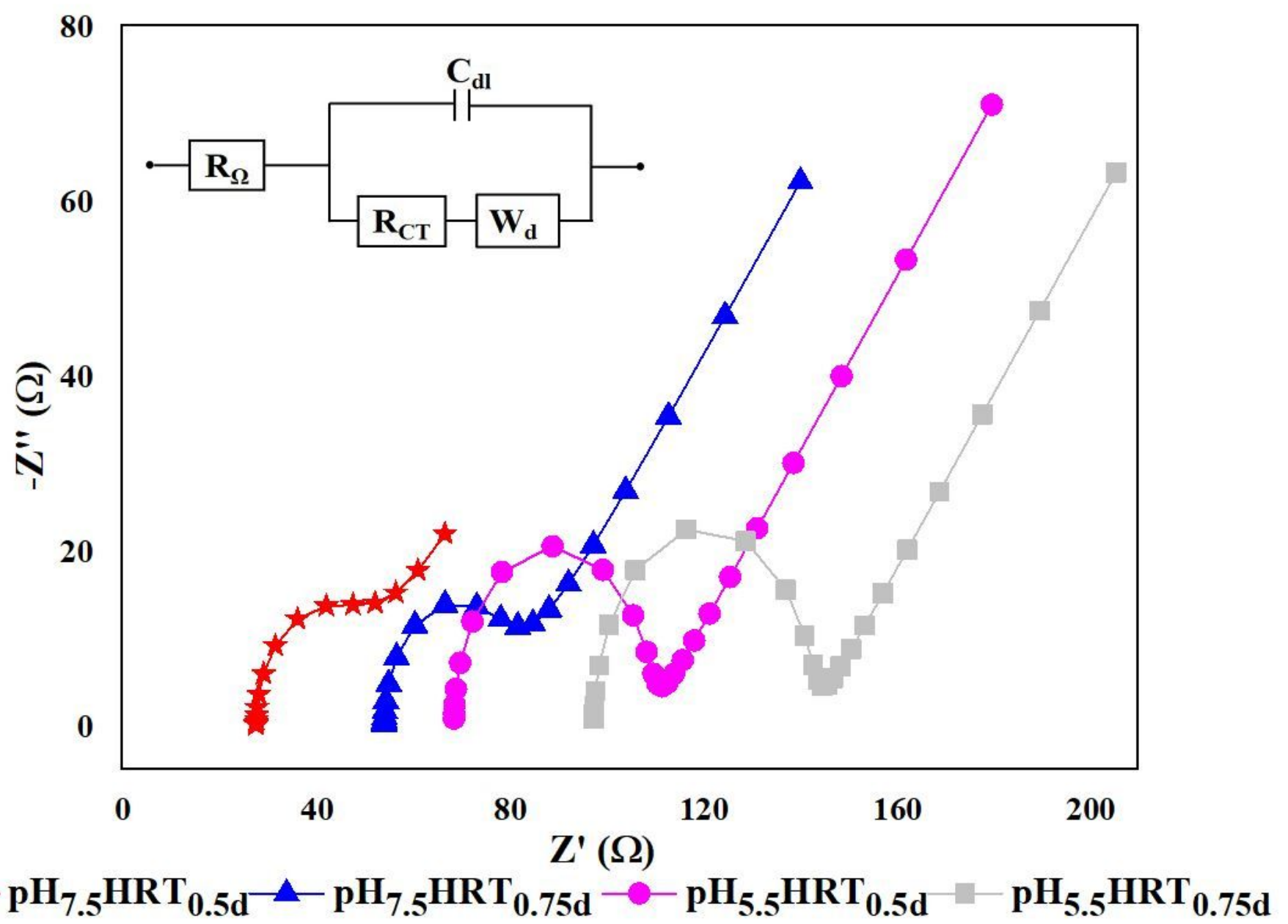

Figure 4

Nyquist plot for the coupled system at different operational conditions. 


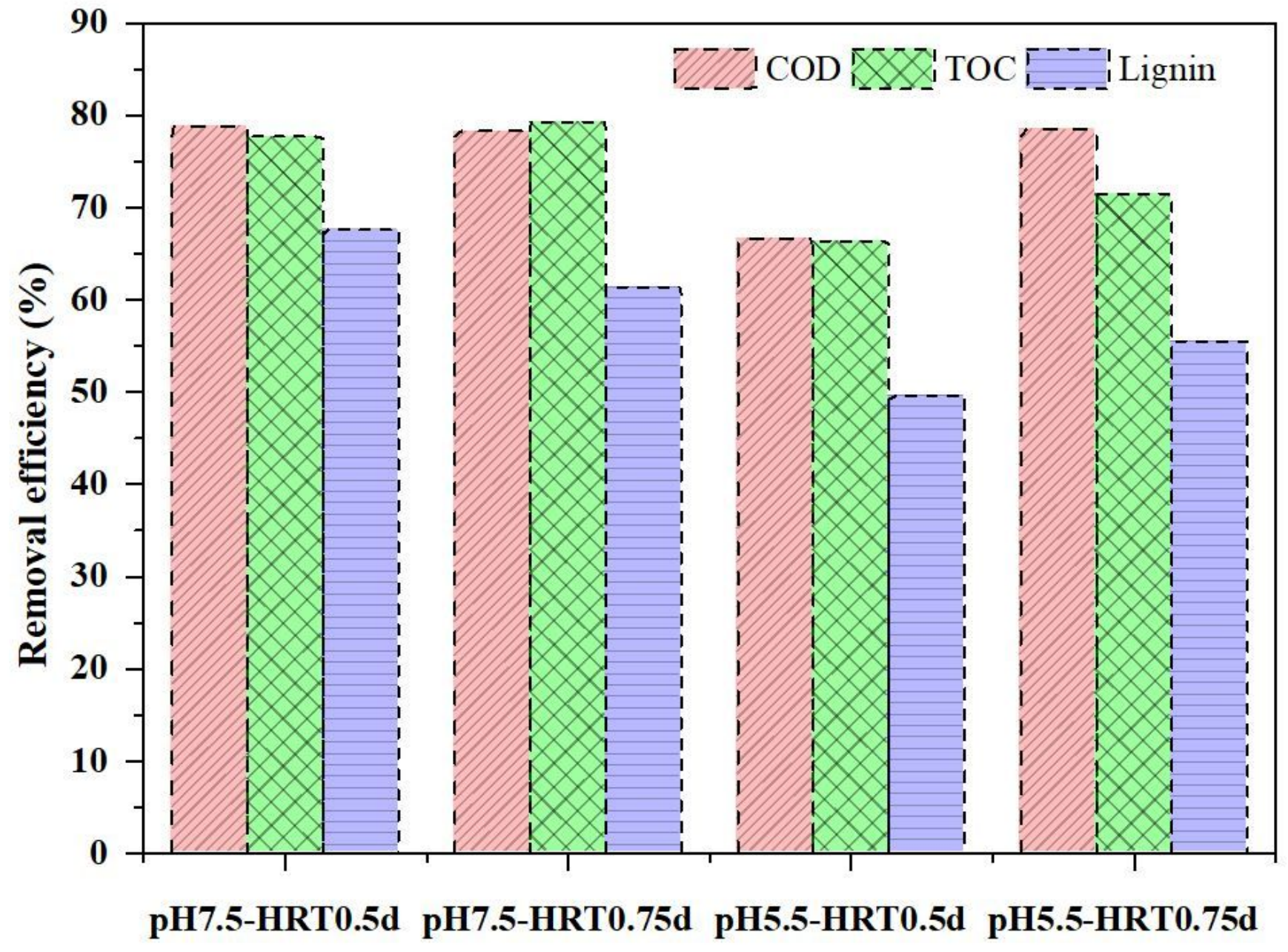

Figure 5

COD, TOC, and lignin removal efficiencies for the integrated acidogenic reactor MFC system 


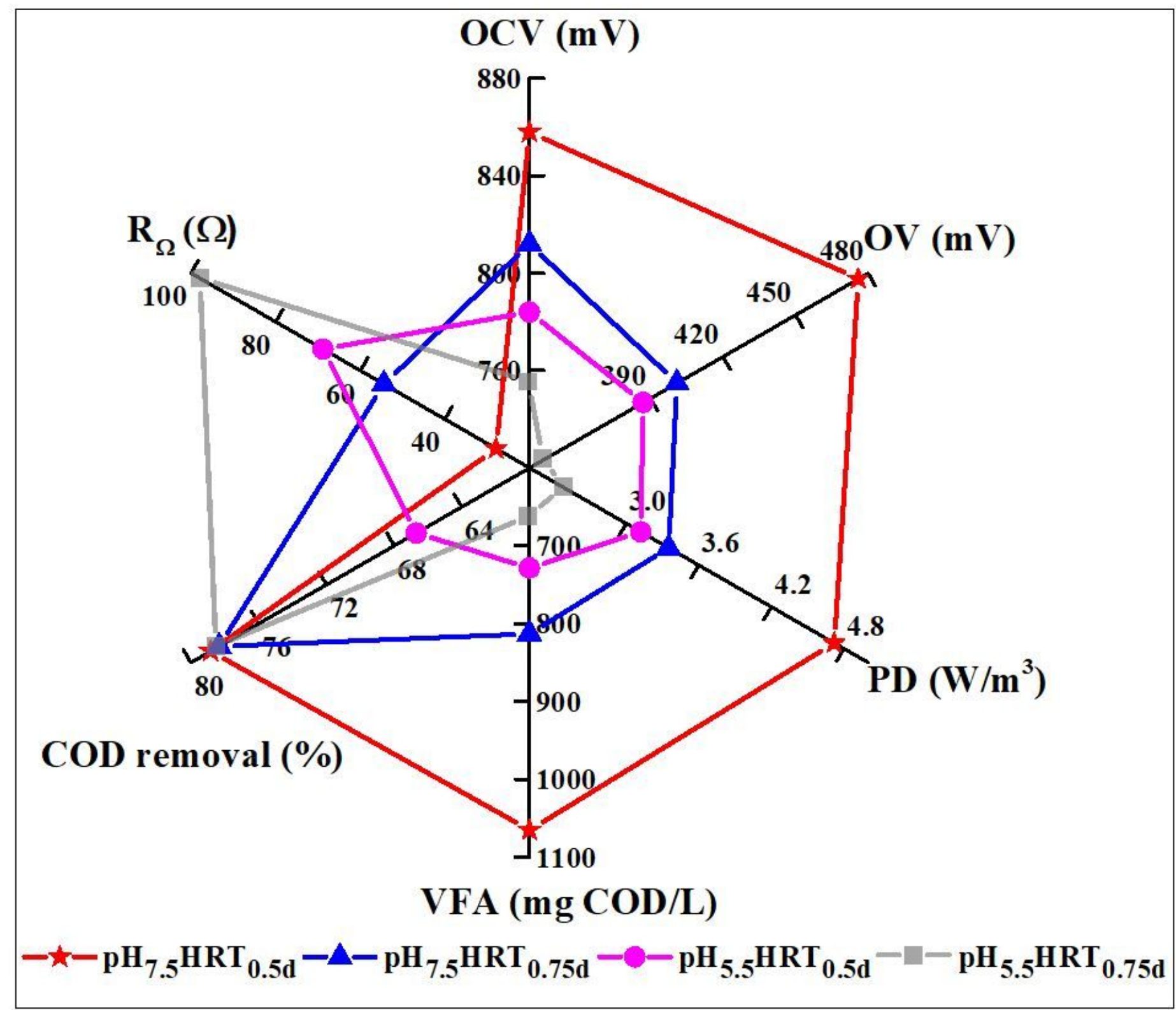

Figure 6

Comparative assessment of the performance of the system at different operational conditions. 